\title{
Transition, Literature and the African Writer
}

\author{
${ }^{1}$ George Anaso(Phd), ${ }^{2}$ Nwabudike, Christopher Eziafa \\ ${ }^{1,2}$ Department of English, Federal University Dutsin-Ma, Katsina State Nigeria.
}

\begin{abstract}
This paper titled Transition, Literature and the African Writer, takes a critical look at the African writer's (the novelist's) concern with Africa's contemporary political scenario which is marked by abuses of power; conical lawlessness, disorder, corruption in all ramifications and bizarre manipulation of the legislative and electoral processes in order to perpetuate arbitrary power, impunity and bad rule. The paper observes that since the abating of the literary fire of the colonial era, African writers have done little to address these corrupt and undemocratic activities in Africa's political scenes. This is due to the fear of elimination, or money/ material allurements by the powers that be. The paper also takes a look at the views of African writers vis a vis Africa's political situation, in order to examine the role that African writers carve out for themselves. After a brief survey of the platform on which African writers perform their role and their inability to address the issues involved. The paper wraps up the discussion with some suggestions on what African writers should do to ensure the political education of the society in accordance with the writers' envisaged role or standing as the sensitive points of the community so as to carry the society along the path to political education and moral sensitization. Key words: Political dictatorship, social engineering, sensibility, Machiavellian dictator, colonialism.
\end{abstract}

\section{Introduction}

The traditional political system in Africa was preponderantly dynastic or monarchical leadership. It autocratic and concentrated in the hands of the traditional rulers or kings, who exercised absolute power over their subjects (Aguru, 1992, Ali, 1994). However, there were some exceptions to this mode, like in the republican traditional Ibo society of eastern Nigeria, where leadership was exercised by age-grades and titled groups through consensus of opinions (Njoku, 1983). None of these systems is democratic because democracy, which involves a representation of the people through the process of election was not practised in the traditional African political system.

Africa's democratic experiment started in the late 1950s and 1960s (and 1970s as in the case of Portugal's ex-colonies like Mozambique, Equatorial Guinea, Guinea Bissau etc).The inherited African democratic experience and political experiment simulate the wobbling of an infant trying to walk. The colonial experience was not a sufficient training ground for Africans in the art of politics and governance. This was because the colonized people were substantially not involved in the art of decision-making during the colonial era, but were made to receive orders meant to be carried out to the letter. Also, owing to their ignorance, the excolonized people were unable to evolve and adopt any other political system than the one bequeathed by the colonial master, which they were led to adopt (Davidson 1992). This way, the newly independent states adopted the political models of their colonizing powers. It was the model that lumped Africans together indiscriminately, not recognizing their separate origins and individual identities.

As a result of the fact that European political system was strange to Africa, it was greatly misunderstood and misapplied when it was ushered into the African arena. This invariably gave rise to confusion and chaos arising from many upsets and conflicts whose roots were varied and difficult to analyze. However, the major problem seemed to have arisen from the colonially imposed social and political institutions within which the colonized Africans lived and tried in vain to survive. In this vein, Davidson (1992:12) sees this problem as a 'crises of institution'. This institution is defined as 'nationalism' that started as 'nationastatism' before independence. Different ethnic nationalities were lumped together in establishing various countries in Africa. The independence later turned out not to be a restoration of Africa to Africans, but the beginning of a new kind of subjection of Africa through indirect rule, the 'divide-and-rule' system. The welded units were forced to unite as nations which tended to represent a time-bomb that would blow off in due course, owing to cultural differences that were irreconcilable. The causes of Africa's political problems arose therefore from the colonizing British and French systems based on the imposed nationalism, not that Africa did not evolve a nationalism of its own that could sustain a civil society with accepted frontiers. The more this unity was forced on the nation-states, the more their differences became expressed and the more the problems that arose to negate the colonial aspirations of joining the erstwhile separate entities as single nations. Rather than use the expression 'nation-state' to represent the solidarity and common loyalty of people who stood among themselves as a nation 
and a culture, the term 'tribalism' was adopted derogatorily by colonizers, thereby distorting the actual social organization of Africans so as to deny their true nationality (Davidson, 1992).

Briefly, the foregoing was the platform on which western political system was engendered in Africa. This paper will therefore address the challenges confronting the African writer in contemporary political climate in Africa, against the backdrop of this scenario serving as pivot for discussion and to view the human transitional characters who make the arena very dangerous for African writers to operate.

\section{Africa in Transition:}

African states are in a transitional state. This is the transition from various nation-states to amalgamated entities through colonialism, to post-colonial and neo-colonial states attempting to grapple with the problems of nationhood and globalization. The whole transitional episodes have been taking place within four to five decades of existence of these countries. However, every transitional era anywhere breeds its own transitional characters, a phenomenon that has been noticed since the medieval era, which prompted Shakespeare to write some of his plays like Macbeth, King Lear, Hamlet etc. If we realize that Africa is experiencing a similar transitional trend which England passed through in the middle ages, we shall then be able to identify such transitional characters in our time as well as their peculiar natures. They are people with insane avidity for power, people whose upbringing has suffered a cleavage, people who enjoy sycophancy and promote such to the detriment of the innocent, people with solidly rigid mind and people who can do anything no matter how horrendous, for personal gains and aggrandizement. (Ogunba, 1972:109). African political scenes are fraught with such people riding on the waves of African tempestuous political scenario.

\section{The African Writer}

The writer, in the sense used in this paper, stands for the literary artist who applies his wok as a discourse to highlight the issues of his society. Here, the views of different writers are cited as the concern of the writer in Africa. To Achebe (1975),

...the writer is a human being with a heightened sensitivity (who) must be aware of the

faintest nuances of injustice in human relations

$\ldots$ the writer cannot therefore be unaware of monumental injustice $\ldots(75)$

which his people suffer

To Achebe therefore, the writer is a person with a keen sensitivity which propels him into the exposure and condemnation of injustice and other social malaise of his environment. In this exposure, the writer shares a good deal of sympathy for the suffering of the society, as declared by Carter (1971) when he states that:

the African novelist frequently does deal with conspicuous suffering...

His people are closer to the edge of experience. He must exercise

Sympathy before he can exercise art ... ( 138)

Sympathy and sensitivity are together in the heart of the African writer, and those characteristics enable him to apply his art to achieve the objective of touching the life of his society.

Another view of the African writer, according to Jones, is that he sees nothing else but evil in his environment, and that he is bound to reflect on them in his works:

The writer today in Africa must see around him bad politics, bad

religion, the misleading of the ordinary people and he is bound to

write about all this if he writes about his environment ... I think

that the writer must write about things that happen around

him ... (54).

To Eldred Jones therefore, the African writer must see only the evils of his society and expose them. There are a few African writers who are decidedly pessimistic while writing about their society as opined by Jones. One of such is T.M. Aluko who, more or less, in his early novels, contents himself with mocking at his society and casting aspersions and cynicism upon his traditional life, for its backwardness and ignorance.

While writers like Achebe and Soyinka try to assert the strength and vibrancy of their cultural lives, Aluko derides his background as doddering and idiotic, perhaps in line with Jones' perception.

African writings have their roots stylistically in such genres of pre-colonial African art-forms as folktales, fables, legends, myths, proverbs, idioms and various forms of chants, songs and poetry. These renditions were used as various ways of social engineering and criticism. African writings are informed by these patterns of traditional art-forms while handling various themes. To Ngugi wa Thiong'o "major African writers see the writer as a warrior who should have an opinion on everything from geography, history, physics, and 
chemistry to the fate of mankind" (46). In continuation of the view on the African writer, SekoToure of Guinea stressed the role of the African writer in the following terms:

There is no place outside the African revolution for the artist or for intellectual who is himself concerned with and completely at one with the people in the great battle of Africa and of suffering humanity. (97)

The opinion of Ken Saro-Wiwa is that "Literature must serve society by steeping itself in politics, by intervention, and writers must not merely write to amuse or to take a bemused, critical look at society. He must play an interventionist role." in his contribution, Ushie also agrees with Saro Wiwa's view when, he asserted:

In the continent as a whole, writers have been in the forefront of (among) cultural producers in the fight for the survival and well-being of the preyAfrica. They have fought consistently on the side of the oppressed right from colonial days ... (27)

According to Niyi Osundare, "a writer in Africa is a person that people look up to, whose works people are trying to see how they relate to the social, cultural and political problems"( 36 )

On the other hand, dictators in Africa generally consider literature and its producers as a threat to them because these often suggest a 'revolutionary path out of their preydom' (46 -7). For instance, Achebe's A Man of the People (1965) and Ayi Kwei Armah's The Beautyful Ones Are Not Yet Born (1965) are examples of such works that end with revolution.

To achieve a balanced discourse of the society, the African writer must show both the good and the bad aspects of his people if he must accomplish the traditional role of a writer- to perpetuate the good and discourage the bad practices. When the occasion calls for the former, he should do so, as in the case of Sol. T. Plaatje in Mhudi (1930) where he defends the custom and traditional life of Barolong people of South Africa from imperialist denigration. In the same vein, Achebe's Things Fall Apart creates a dignified image of his society and tradition while not hiding its faults; yet, he turns into an angry reformer in A Man of the People (1965), The Trouble with Nigeria (1983) and Anthills of the Savanna (1987) to chastise the society for going astray. Achebe took his time to condemn Africa's political immaturity which often leads to political turmoil and military interventions in politics. This is the interventionist role that the writer is expected to play in his world, according to Ken Saro-Wiwa.

\section{Africa's Political Scene Today}

The contemporary Africa is characterized by turmoil and rancor which arise both from ethnic rivalry, the failure to conduct credible elections and brazen distortion of the democratic process in favour of sectional interests and dictatorial ambition. For this reason, the practice of western democracy has become a farce and mockery of the system. Rather than usher in justice, equity and good governance, politics in Africa has perpetuated civil unrest and its attendant destruction of human life and resources. All through Africa, democratic elections have become synonymous with macabre operations of gruesome intra and inter ethnic strife. The manner in which these elections are conducted shows that the motives of the operators are uncanny and in utter disregard of the rule of the game. It is not, as it is often claimed, to give appropriate and objective leadership to the society. This is because such a genuine motive would not inspire a do-or-die attitude for a situation that calls for purely altruistic service to the community.

Contemporary African political arena has its double share of brutes and beasts in the form of dictators criss-crossing Africa from North to South and East to West. These dictators wholly reflect the transitional characters mentioned earlier. Many have been violently uprooted by force, while some are still waiting for stronger a force to eradicate them like noxious pests. One cannot mention any African country without attaching a dictator, past or present, to it. Power drunkenness is therefore a common cause of strife and political turbulence in Africa, apart from cultural and ethnic diversities of these countries.

Instances of political strife in Africa include the Zimbabwean election crisis, the bloody strife in Kenya that almost resulted to a full-blown civil war, the Rwandan crises between the Huttus and the Tuttis, the civil wars in Liberia, Ivory coast, Sierra Leone, the Nigerian civil war of 1967 - 1970, the frequent political debacle, the militancy in the Niger Delta and the Boko Haran insurgency in the North. Civil unrest has continued to attend the political scenario in Ethiopia, Somalia, Madagascar, Mali, Burkina Fasso, Tchad Republic, Sudan, Congo Democratic Republic, Libya, Egypt, and others. In all these states, the remote cause of these crises is the lumping of various ethnic nationalities that could have remained separate, into one nation by the former colonial powers. According to Davidson, these crises resulted from the "degradations from the hopes and freedoms of newly regained independence (12)".

Secondly, human blunders and corruption manifested in the tendency of Africa's neo-colonialist dictators to grab power, abuse office and indulge in avarice have contributed to Africa's political instability.To 
these rulers, political power is seen in the perspective of winner-takes all and for keeps; only being separated from it by death. These greedy rulers see their countries as their personal enterprise which they must adequately secure against passing over to another poacher. This is the common monstrous characteristic of neo-colonialism in contemporary Africa.

The social background of the African continent dictates the political en passe that continually attend to its history, as well as the attitude of its writers to its political situations. It is for this purpose that Mphahilele (1982:36) sees the artist as the sensitive point of the community. Along this line, Soyinka declares optimistically, that the artist has the power to redeem his community from the fatality and horror that surround it. Also, in his own contribution as to what the writer should be concerned with, Achebe posits:

Without belittling the efforts so far of our writers, it is time we abandoned the pursuits of the shadow and grabbed the substance ... it is this greater concern with the affairs of the society ... that I mean, not with the system (colonialism) that no longer holds sway ( Nwoga 19)

The 'affairs of the society' which Achebe refers to and which subsequently informs his later works are related to its social and political life. For this reason, Achebe's later works' concentration is on the substance (the affairs of the modern state) rather than the previous concentration on colonialism and its effects on the formerly colonized society.

Anaso (2006) sees the concern of the postcolonial writing as the simulation of the immediate medication for an ailment which would no longer be needed after the ailment has been cured. This is because the former colonies are now independent, trying to grapple with the affairs of development, democratization, and globalization, no longer with smarting under the yoke of colonialism.

However, Africa's political and social crises are, nevertheless, the offshoot of colonial experience, which the ex-colonized people passed through during the European conquest and domination. Europe perpetrated and perpetuated Africa's woes from the onset of colonialism. Historically, when the colonial administrators demanded for youths to be trained in their schools to raise the first crop of colonial messengers, interpreters, court clerks and even soldiers, the suspicious natives released to them mere delinquents. These were later deployed after their schooling as (colonial) workers in the Whiteman's service, used to brutalize their own people, as shown in some African novels which documented the anecdotes.

This first level of colonial employees manifested the "superiority" attitude towards their kith and kins in the community, exercising an unwarranted authority over their people due to their association with the Whiteman. An example of this authoritarianism is manifested in Achebe's Things Fall Apart when a courtmessenger appeared with the assumed air of power and importance as the Whiteman's emissary, to announce to Umuofia Community: "the Whiteman whose power you know very well has ordered this gathering to disperse". It could only take an irascible and irrational neurotic like Okonkwo to try to put an end to this 'impudence' of a court messenger (locally referred derogatively to as Kotma). This is the kind of authoritarian attitude assumed by these workers, puffed up with a mentality of self importance and megalomania.

Also, at a later time when the colonized people started embracing western education, a few privileged ones were sent abroad to the mother countries for ideological brain-washing called Western education. These later became the African elite that came to assume power from the whitemen's legacy in the colonies. The only difference between independence and colonialism is that political offices are held by blacks, and the colonial loyalty remains those of the colonialists. This is evident in the statement by Gabon's first President Monsieur Bongo at independence: 'Gabon has independence, but between Gabon and France, nothing has changed, everything goes on as before'

(Fannon, 1967:66).

This however suggests why neo-colonial Africa cannot change the inherited modes or systems of those that colonized and despised it; or modernize from the models of its own history or invent a new one. In the language of a one - time O. A.U (Organization of Africa Unity) Secretary General, Edem Kojo; "Africa may have space, people, natural resource ... but Africa is nothing, nor can do anything" (Kojo, 1992). After all, many African countries still depend on aids from the ex-colonialists to balance their budget deficits annually. In Nigeria in particular, political power tends to veer towards lawlessness and brazen disregard to the constitution of the land. For instance, the constitution provides for a three tier system of governance. The governors have however constituted themselves into dictators who work against this system by completely refusing to allow the third tier (the local government system) work; rather, they fight against the system to ensure that it is derailed. By derailing the system, the governors now hold their grips on the monthly allocation for the Local Government, which is their aim to control, without using the allocation to develop the grassroot polity. 


\section{The African Writer And The Political Crises In Africa}

Politics is one of the most critical elements that touch human life both as individuals and as nations. In a wider sense, it touches on the life of the entire mankind, apart from other social elements like religion and economy, which also have political linkages. Since politics is the major element that affects the totality of human life, major crises in human life also arise from politics. The writer uses his art as a discursive mode to analyze the nature, operations and consequences of political crises in the society. In this role, the writer responds to the social image of the sage, visioner or elder as in the traditional African community, who should call the society to order if it goes astray. This is in line with an African adage which emphasizes that "a fly that has no one to advise it often accompanies the dead body into the grave". Despite the deliration of events, characters and action, there is the underlying concern among writers with order, stability, equity and progress. Their societies lacked these in sufficient quantity because the conflicts and chaos that followed them emanated from their problematic entry into the world created by European domination and modernization. For instance, the ending of A Man of the People in a military coup manifests the logical correlation between art, vision and objective deduction which has made some critics to erroneously infer that Achebe pre-empted the Jan. 1966 military coup in Nigeria.

Chinua Achebe, whose works include A Man of the People (1965), The Trouble with Nigeria (1983) and Anthills of the Savanna (1987), (all political tirades) has examined the political crises in Africa. In summary, Achebe's A Man of the People is a critical view of the problems that attended the democratization process and the corruption inherent in the political governance of new independent African states. In The Trouble with Nigeria, Achebe clinically examines the issues of governance and why Nigeria, like many other African countries, cannot progress politically. He states:

The trouble with Nigeria is, simply and squarely, a failure of leadership

There is nothing basically wrong with Nigeria character. There is nothing

Wrong with the Nigeria land, or climate, or water, or air, or anything else.

The Nigeria problem is the unwillingness or inability of its leaders to rise

To the responsibility, to the challenge of personal example, which

are the hallmark of true leadership ... (76).

Since 1983 after the release of this work till 1999, Nigeria witnessed six dictatorial military regimes. It is only from 1999 to date so far that civil rule has endured the longest time, with a lot of hiccups. Even then, no one is unaware of the doddering and corrupt nature of the civil rule. An incident in the mid August, 2008, in which high-ranking military officers were retired from service, lends ground to the insinuation in some quarters that the army may have desired to come back to power despite the much vaunted protenionalization of the military.

By his comment in The Trouble with Nigeria. Achebe shows the role of the artist (or writer) in the society to draw a correlation between Art and Politics in their concern with equity, justice and fairness, which should represent the key-pillars of the modern nation states in Africa. The absence of these elements is the major cause of confusion and chaos heightened by mutual suspicions of the multi-ethnic and multi-lingual nationalities of these countries.

Another Nigerian writer, T.M. Aluko is concerned more with social change than with politics. Even when he writes on the theme of corruption as in Chief the Honorable Minister (1970), his concern is more on the tainting effect of traditional life which, to Aluko, is rooted in corruption and 'lack of certain standards', (Taiwo, 1976) than on political rule per se. This is in line with the earlier work titled Kinsman and Foreman (1965) where official corruption is linked to tradition and character.

Soyinka's political discourse in his play, A Dance of the Forests (1960) was his response to the attitude of national euphoria that greeted Nigeria's independence in 1960. This play made its debut on the eve of September 30, 1960 and its intention was to warn the nation on her high expectations about independence. The writer linked the past (the so called great empires of Ghana, Mali, Songhai etc) with the immense unreported corruption there to the corruption and evils of the present generation, in order to show that the future of the people cannot be different from the past and the present. To achieve this linkage, the writer manipulates the issue of reincarnation to show how some of the criminal characters of the old, reincarnated as evil doers and corrupt people of the present generation.

Also, Soyinka has written other political books, especially those prison works like A shuttle in the Crypt and The Man Died which he used as satirical comments on the military during the Nigeria civil war, when he was incarcerated in a maximum security prison in Kaduna, for condemning the civil war.

Africa has fought several major political wars either for independence or as political turmoil and crises. African writers played a major role in all these conflicts in order to achieve independence and freedom through their works. However, the relative peace that followed is also always marked by lack of writings. The writers' pens appear to dry up in ink as can be seen in the cases of most known African writers like Soyinka, Aluko, 
Ngugi, Awoonor and Achebe, most of whom are aged, now in their mid seventies and eighties. Young writers seem to be less militant and uninspiring than the old ones.

Yet, Achebe is still tenacious in his attachment to equity, justice and fairness. In 2004, he was to be awarded a national honors by the federal government of Olusegun Obansanjo. This award was astutely refused and rejected by Achebe, who saw his acceptance of it as 'pandering with injustice and corruption', The Guardian, New Nigerian and Daily Thrust newspapers all, of $9^{\text {th }}$ October 2004 recorded this episode accordingly.

It is not surprising then that very little critical works (if any) on government's misrule are noticed today, in spite of the avalanche of illegitimacy and criminality observed every day. How can Nigerian writers be tongue-tied over protracted teachers' and workers' strikes, over the brutal massacre of Niger Delta people for protesting against the unremitting exploitation of their lands with the attendant degradation and pollution, over the unmitigated corruption in high places, over government's lack of concern for the provision of electricity, water and good roads; over the unchecked armed robbery cases, kidnapping of innocent citizens and total lack of security, over the marginalization of some sections of the country both politically and in provision of social amenities and infrastructures, and over government's callous indifference to unemployment which has clocked the all time mark of over forty percent (40\%), according to Uttuedon. (2008)

These are apart from the Spiraling inflation that has rendered the nation's currency a laughing stock in the world financial markets. Where are the Nigerian writers in the face of all these social ills, beckoning for redress? This scenario is merely a child's play when compared to Zimbabwe, although it is not intended to compliment Nigeria and other African countries with similar conditions.

\section{Problems Of The African Writer}

It can be said that African writers who write and criticize authoritarian rulers in Africa run grave dangers of losing their lives. The major reason is that the hardhearted African dictators would not brook any opposition to their authoritarianism. It is either the critics (writers) yield to the allurements of these Machiavellian rulers and write in agreement with government's actions or shut up. For this reason, most vibrant writers have been silenced or decided to play it cool; except of course, those living abroad in self-exile. Achebe was able to make the courageous comment in 2004, that Nigeria's condition was too dangerous for silence, because he was permanently residing in the United States of America. On October $19^{\text {th }} 1986$, a vibrant journalist, Dele Giwa of the Newswatch Magazine, who refused an offer in order to rescind from publishing what "the powers that were" considered as damaging, was supposedly eliminated through a letter-bomb delivered to him. Cases like this that occured through other brutal elimination processes contribute to the problem of writers in contemporary African societies.

Also, in the roaring days of Abacha, Ken Saro-Wiwa and eight of his Ogoni compatriots were hanged for asserting their human rights, apart from the innumerable activists fed the crocodiles in a pond put in place for that purpose behind the Aso Villa. Larson, (2001) observed that African writers have ended up suffering 'more indignities, threats, humiliations and genuine terror than their counterparts in the rest of the non-western world'. Osundare, (1992) in his own observation, views Africa today as a dangerous place to think a risky place to argue'. This is why it is probably necessary to qualify Soyinka's declaration that the writer has the capacity to deliver his society from the fatalities and horrors that surround it with the provision that the writer is able to grapple with repressive and dangerous forces that may stand against him. This is based on the fact that some African writers in Nigeria, Sierra Leone, Liberia, Rwanda, and the Congo etc have decided to lie low and not read the dangerous path. Others have adopted certain features in their writing that make their insinuations less obvious. These include applying symbolic representations and pseudonyms both of authors and characters in the books.

Another problem, although less threatening than the first, is the issue of poor readership of literary works nowadays. The society has grown lazy and become inveigled by other sources of distraction like satellite television programme, internet browsing and the social media and sporting activities; to the extent of not having much interest, energy and time left to read intellectual works, especially African literary works. In some cases, people cannot afford to buy these books and read, owing to economic pressures. It then implies that the books do not sell much or there is lack of patronage for them after publishing. This partially accounts for the dwindling intellectual status of the nations of Africa, where the masses are still impoverished economically and intellectually.

Linked to the issue of poor readership is the attitude of publishers, both western and local, manifested in their preference to publishing school texts, which yield more and quicker returns. This has added more burden to African writers, and so, more discouragement; but nevertheless lends a helping hand to the African dictators who would spare no effort to blunt the pens of African writers who have proved a thorn in their flesh; especially with works toeing the path of revolution as solution to Africa's political problems and social liberation. 


\section{Meeting the Challenges of Contemporary Politics by African Writers}

To meet the challenges of contemporary African politics, African writers should acknowledge the following facts (and I believe they do):

- that the political terrain in Africa today is fraught with many dangers' making the lives of writers (and their jobs) unenviable and risky. Even the Peer Review Mechanism titled New Partnership for African Development (NEPAD) cannot be said to yield any positive end in checking political abuses, because it is only a ploy instituted by the political like-minds to cover their misleading of their people;

- that the African leaders in general is not sufficiently educated to acknowledge that the sanctity of rights and privileges of individuals and groups within it should be respected and honoured;

- that, as a result of ignorance and sheer hard-heartedness of political rulers humanrights and liberties are taken for granted and trampled upon with impunity by those who are in office and who flagrantly abuse power, expecting their subjects to be absolutely subservient to them, even when such leaders are known to fan the embers of sectionalism and parochialism; and to chart the course of graft and avarice;

- that there are religious and ethnic diversities emphasized in the body - politics of various countries from which unavoidable conflicts of interest erupt frequently;

- finally, that there is immense corruption in the entire political processes in Africa, and that this corruption is deep-rooted, arising from lack of proper moral education (a training process for future leadership) Edem Kojo opines that:

Africa may have space, people, natural resources among other things, but Africa is nothing, does nothing, nor can do anything to deliver itself from human failures and corruption that it is plunged into ..." (12). This statement was made against the issue of political conflict in the Republic of Chad with its petty-minded and violent political conflicts, its drought, its underdevelopment and its systematic self handicapping, which sometimes seems a paradigm of African dilemma.

The African writers' challenges are quite enormous; owing to the intrinsic background of Africa which has for ages shaped its existence. This perhaps has informed the statement of the world acclaimed Reggae master - Bob Marley, when applied to Africa's situation, that 'two thousand years of history could not be wiped away so easily'. The implication is that it will take a long time with enormous political and social engineering to bring Africa along the track of the civilized world politically.

Looking at the image of the African writer as a teacher, according to Achebe, (1975) the writer should be patient, like a teacher, and not expect the job of a century to be concluded in a short time, seeing that Africa is politically toddling. Nevertheless, the writer should continue, to work through constructive criticism and persuasive corrections, to educate the society and like a sage, advise it where it goes wrong, whether anyone appears to listen or not. This is a sacred duty that should not be abandoned due to frustration and negativism on the part of politicians who, like the transitional character, may turn to political terrorism to frighten away critics.

Apart from instructing the political aspirants on the aims and challenges of political office, the masses should also be educated on their rights and duties of electing credible people into offices and of disowning their elected representatives when they betray or abuse the confidence of the electorate. This political awareness should be incorporated into the school curriculum. This is why Achebe, in A Man of the People applies cynicism in referring to the common people's endorsing attitude to corrupt politicians when they ask: 'who in his right mind will spit out a juicy morsel put into his mouth by a benevolent spirit', and ..... 'after all, when the white man was doing all the chopping, did we commit suicide?' This was the trend of reasoning by the common people to justify Chief Nanga's corrupt attitude. The writer should also disabuse the minds of the illiterate and ignorant masses on matters relating to corrupt politicians.

Also, the writer's position calls for moral uprightness and conscience to be able to stand firm in resisting allurements from political office holders. Some writers have been known to shy away from performing the sacred duty of directing the society along the path of rectitude, once their 'palms' are 'greased'. Those writers who allow themselves to yield to undue pressure from the establishment and cannot astutely resist such pressure, do not really have the calling. This sometimes may have to do with poverty and economic constraints which such people are into. The saying that 'if you cannot beat them, you should join them' should be ignored for 'if you cannot beat them, leave them,'

The writer should stand in the image of Thomas More in Robert Bolt's A man for all Seasons, who boldly tells the court of King Henry VIII (set up to try him for treason) that: when a statesman forsakes his private conscience for the sake of his public duties, he leads his nation by the short route to chaos' (12). The writer must emphasize absolutely the place of conscience in all matters.

This statement is in line with Achebe's stand in The Trouble with Nigeria when he condemns the unwillingness of the leaders to rise to the challenges of leadership by personal example, and so points to the way forward: Writers are expected to point to the way forward for their people.

Finally, writers cannot write in complete detachment or isolation from one another. When they realize that there is an urgent and inalienable duty to address, they should do it in a unity of purpose as a common 
cause. This calls for a united front through an international (or national) association to which writers in Africa should subscribe their membership. In the past, there was a body known as the Commonwealth African Writers Association, to which all the known names in African writings belonged. This body was very vibrant in the postcolonial literature and contributed in a large measure to African liberation struggles. A similar body can as well be formed to direct its attacks against the rampant authoritarian tendencies of the undemocratic dictators in Africa. Such political terrorists like Mugabe and other sit-tight rulers who cast slur on the image of Africa, who degrade the hope of their people should be exposed, attacked literarily and removed from offices. It is said that "the pen is mightier than the sword". This has to be proved in Africa once again. African writers who in their attempt to unseat authoritarian regimes in Africa, will surely enlist the sympathy and backing of the free and democratic world to succeed in the ploy, if they should heed to the above suggestions.

\section{Conclusion}

The political terrain in Africa is fraught with many dangers as a result of do-or-die attitude involved in the struggle for political power. The main reason for this attitude is that politicians are inspired by the tendency of looting the coffers once in office. The attitude is not checked in Africa because of the common roguish nature of the people involved and lack of the instruments for checking graft in Africa. The position of the writer in Africa is therefore dangerous because he sees all this but could not do much to tackle the abuses effectively, owing to the risks of either incarceration or elimination through gruesome processes. This is why it appears as if the sword has become mightier than the pen. Africa is not comparable to the Western world where the course of democracy is charted. There is, nevertheless, a glimpse of hope that the democratic process is gradually taking root in the continent, with South Africa and Ghana blazing the trail with the recent successful conduct of democratic elections in those countries. It is believed that these good examples will inspire and betake other African countries. Also, it is believed that rampant humanrights abuses and violation will gradually reduce, thereby giving African writers the freedom to express themselves and the empowerment to curb the political terrorism in the continent. It is only then that the supremacy of the pen over the sword can be established in Africa.

\section{Works Cited}

[1]. Aguru, Okenu B. Social Organization in Pre-Colonial Ibo society of Eastern Nigeria Onitsha: Varsity Press. 1992

[2]. Ali Samson A. 'Nigeria in History: A Study of the, Political Development of Nigeria 1960-1993, paper presented at NUJ / NGE Conference held at Minna July, $7^{\text {th }} 1994$.

[3]. Njoku, Fred O. Neo-Colonialism and Africa (ed Sydrey Oforje) Benin City: Squire And Brierrs. 1983.

[4]. Davidson, Basil The Black Man's Burden, Ibadan: Spectrum, 1992.

[5]. Achebe Chinua, Morning Yet on Creation Day ... London: Heinemann 1975

[6]. Carter, D. "Sympathy and Art: Novels and Short Stories, in African Literature Today" New York: African P.C. 1978.

[7]. Jones, E. 'Locale and Universe three Nigeria Novels', The Journal Literature (ed. James Currey,1993).

[8]. Fannon Frantz: The Wretched of the earth GE. Britain; Penguin 1967.

[9]. Wiwa, Ken-Saro A Month and a Day. A Detention Diary, Ibadan: Spectrum Books 1999.

[10]. Ushie, Joseph A. 'Many Voices, Many Visions: A Stylistic study New Nigeria Poetry. An unpublished doctoral thesis submitted to the faculty of Arts, University of Ibadan, Nigeria, 2001.

[11]. Osundare, Niyi. Great African on the Record: A Dictionary of African Quotations. (E.d. Omuabor). Lagos: 1992

[12]. Mphahlehle, Ezekiel. The African Image. London: Heinemann. 1982.

[13]. Larson, Charles R. The Ordeal of the African Writer: London and New York: ZED Books, 2001.

[14]. Soyinka, Wole A Dance of the Forests: London, Ibadan: Heinemann 1960.

[15]. Oladele, Taiwo. Culture and the Nigerian Novel, London: Heinemann. 1976.

[16]. Uttuedon, S.F. 'An Appraisal of Nigeria's Economics Status', paper presented at a symposium organized by the National Association for Socio-Economic Research at the Bolingo Hotels and Towers, Abuja on April 24 ${ }^{\text {th }}, 2008$.

[17]. Nwoga, D.I. (1978) Literature and Modern West African Culture, Benin City: Ethiope. 